\title{
Research Production at King Khalid University: Perceptions, Challenges, and Suggestions for Improvement
}

\author{
Fadi Maher Al-Khasawneh ${ }^{*}$, Mohammad Ahmad Al-Khasawneh ${ }^{2}$, Mohammad \\ Abedrabbu Al-Khawaldeh ${ }^{3}$ iD \\ 1,2,3 King Khalid University, Abha, Saudi Arabia \\ *Corresponding author: falkhasoneh@kku.edu.sa
}

\begin{abstract}
Abstrak
Penelitian ilmiah sangat penting karena memberikan kontribusi bagi pembangunan bangsa-bangsa di dunia. Namun, ada kelangkaan penelitian empiris yang dilakukan untuk menyelidiki tantangan produksi penelitian di antara anggota fakultas di universitas. Penelitian ini berusaha untuk menggali persepsi, tantangan, dan saran untuk meningkatkan produksi penelitian di King Khalid University, Arab Saudi. Kuesioner) digunakan untuk mengumpulkan data dari penelitian ini. Sampel penelitian ini termasuk 55 anggota fakultas dari Fakultas Bahasa dan Terjemahan di Universitas King Khalid. Temuan mengungkapkan bahwa masa tunggu yang lama untuk publikasi naskah, kurangnya alokasi waktu untuk penelitian, dan kurangnya program pelatihan penelitian adalah tantangan yang paling menonjol dalam produksi penelitian. Para peserta juga menyampaikan beberapa saran untuk meningkatkan produksi penelitian seperti mengadakan program pelatihan penelitian, memberikan insentif penelitian, dan menyediakan fasilitas penelitian yang memadai.
\end{abstract}

Kata kunci: Penelitian Akademik, Produksi Penelitian, Fakultas Bahasa dan Penerjemahan, King Khalid University

\section{Abstract}

Scientific research is very important since it contributes to the development of nations worldwide. However, there is a scarcity of empirical research conducted to investigate the challenges of research production among faculty members at universities. The present study seeks to explore the perceptions, challenges, and suggestions to improve research production at King Khalid University, Saudi Arabia. A questionnaire) was used to collect the data of the present study. The sample of this study included 55 faculty members from the Faculty of Languages and Translation at King Khalid University. The findings revealed that the long waiting period for manuscript publication, lack of allocated time for research, and lack of research training programs were the most prominent challenges in research production. The participants have also stated some suggestions to improve research production such as conducting research training programs, providing research incentives, and providing adequate research facilities.

Keywords: Academic Research, Research Production, Faculty Of Languages And Translation, King Khalid University

\begin{tabular}{ll}
\hline History: & Publisher: Undiksha Press \\
Received : February 09, 2021 & Licensed: This work is licensed under \\
Revised : February 13, 2021 & a Creative Commons Attribution 3.0 License \\
Accepted : March 14, 2021 & Cc)
\end{tabular}

\section{Introduction}

Scientific research is a systematic work that involves solving a problem and discovering facts about it; it is also considered as one of the indicators of development and growth in any society (Batooli \& Nazari, 2014). The significance of the research is drawn from the fact that the most developed countries worldwide have high and developed research facilities (Sotodeh, Ghorbani, \& Rashidy-Pour, 2014). The best scientific research involves systematic procedures of data collection, clear research methodology, and discussion in order to find a solution for the problem under investigation (Burton \& Walters, 2013). Scientific research is normally conducted at universities and research centers. Faculty members and postgraduate students are the two main groups who conduct research. The reasons for research publication among those groups are to get academic promotion for faculty members and to fulfill graduation requirements for postgraduate students (Okoduwa et.al. 2018). Yet, the previous literature on this field has revealed that most of the time that faculty members are spent on teaching rather than research publication (Sotodeh, Ghorbani, \& Rashidy-Pour, 2014). 
The Kingdom of Saudi Arabia has put considerable attention on science as a major means to reach the wanted progress and growth to the people of the country. The vision (2030) launched by Saudi Arabia in (2016) included scientific research as one of the pillars of development and growth to be achieved by (2030). The vision of the Kingdom of Saudi Arabia emphasized sustainable development and competitiveness to ensure a secured economy. The previous literature indicates that any development plans should be based on scientific research, as a result, world countries spend a huge amount of money on research in order to achieve their goals.

King Khalid University is one of the prestigious universities in the Kingdom of Saudi Arabia. It achieved the fourth rank according to World Universities Ranking (QS) in (2020). The university encourages faculty members to publish research papers in prestigious academic journals. For that purpose, the university has launched three research programs (i.e. general research program, small research groups, and big research groups). Each one of these programs provides specific financial support to publish research papers under the name of the university. The university believes that the results of the published research are extremely important in boosting the educational, social, and economic prosperity of the country. However, the number of annually published research at the university is still substandard and needs to be increased. The reasons for the low rate of annually published research at the university might be attributed to different factors and problems. Therefore, the present study aims at exploring the perceptions and challenges of research production among a group of faculty members at King Khalid University. This study also provides some suggestions for increasing and improving the research production in general and at King Khalid University in particular. For this purpose, the present study seeks to give answers to the following research questions: (1) How do faculty members at King Khalid University perceive research publication? (2) What are the challenges facing the faculty members at King Khalid University in research publication? (3) What are the recommendations to improve research publication as suggested by faculty members at King Khalid University?

Shauman \& Xie (2003) indicates that research production is the main indicator of success among employees in general and faculty members in particular. Research production is a key factor to measure the quality of institutions and universities. The most famous university rankings such as World University Ranking (QS), and Times Higher Education (THE) ranking put a considerable portion on research production as one key criterion before releasing the ranking of world universities. Research production is a method used by many universities to assess the performance of faculty members. It is also one of the prerequisites for promotion, salary increment, and contract renewal purposes. The prestige and fame of academic departments are determined by the total number of publications and the number of citations of its faculty members (Gonzalez-Brambila and Veloso, 2007). Fawzi \& Al-Hattami (2015) argued that to get more knowledge about research production, it is pivotal to investigate the factors that might negatively affect research publication among faculty members.

Many reasons could prevent faculty members to write and publish research papers. Abouchedid \& Abdelnour (2015) pointed out that the research production of Arab faculty members is still substandard and relatively low. They attributed the low research production to what they called 'institutional factors' such as job satisfaction, involving them in research, and the attitude of the university mission toward research. Salazar \& Acosta (2008) indicated that most of the faculty members attributed the low research production to the weak culture of research in their institutions. In contrast, Kendangor, Kosegi, Tuitoek \& Chelangat (2012) believe that workplace features and climate are extremely important to improving research production. Hoffman \& Koufogiannakis (2014) indicated that the most institutional factors which would negatively affect research production are: lack of institutional research fund, 
teaching load, lack of research resources, and lack of research collaboration among faculty members.

On the other hand, Zhou (2015) claimed that individual factors such as academic experience, academic rank, gender, age, teaching load, and research interest have also a vital role in research production among faculty members. However, Webber (2011) claimed that there is no significant relationship between research production and gender. In a similar vein, Angaiz (2015) argued that the allocated time on research publication is one of the individual factors that hinder research production among faculty members; while Creamer (1998) emphasized the role of marital status and gender in research production among faculty members. Among other factors that affect research production, cultural barriers (Alzahrani, 2011); academic rank (Stafford, 2011); lack of interest in research publication (Williams, 2013); lack of confidence (Kasetsart, 2009); and lack of research competence and skills (Kendangor, et al, 2012) were reported as important factors affecting research production.

Several studies (Alzahrani, 2011; Fawazi \& Al-Hattami, 2015; Dadipoor, Ramezankhani, Aghamolaei \& Moradbadi, 2018; Hagan, Armbruster, \& Ballard, 2019) have been carried out to explore the challenges facing faculty members in research production. Alzahrani (2011) investigated the barriers facing faculty members in Saudi Arabia concerning research publication. The sample of this study contained some academic staff working in Saudi Arabia. The researcher used a questionnaire to collect the data of his study. The findings of this study reported that the lack of peer encouragement, lack of research funds, lack of research facilities were the most important challenges that affect the research production among the sample of this study. Fawzi \& Al-Hattami (2015) studied the challenges facing faculty members at Bahrain Teachers College, the University of Bahrain when they wish to publish research papers. The participants of this study were 28 faculty members at that college with different academic ranks. The findings of this study revealed that faculty members reported that insufficient time due to teaching load was the most important challenge facing them in research productivity.

Dadipoor et al., (2018) explored the barriers facing medical students in research publication. The sample of this study contained 400 medical students from Hormozgan Medical University in Iran. The researchers used a questionnaire to collect the data of this study. The findings of this study revealed that there were individual and institutional factors affecting research production among medical students. Among the individual factors, lack of research knowledge, and lack of interest in research publication were the most prevalent factors reported by the medical students. Concerning the institutional factors, the findings showed that the limited access to research resources was the most important barrier facing medical students in research publications. Hagan et al., (2019) investigated the research publication barriers among faculty members at Public Health Sciences University in the United States. A survey questionnaire was used to collect the data of this study. The participants included 86 faculty members from Nursing, Dentistry, and Allied Health departments. The findings of this study revealed that 'lack of allocated time in conducting research, 'research facilities', 'lack of research funds', were the most prevalent challenges facing the faculty members in conducting research.

\section{Methods}

\section{Research Design}

The present study adopted the quantitative research design. A questionnaire adapted from Okoduwa et al., (2018) was used to collect the data of the present study. 


\section{Participants}

A total of 55 faculty members from the Faculty of Languages and Translation at King Khalid University, Saudi Arabia were enrolled in this study. The following table shows the participants' demographic information which included gender, age, and years of experience.

Table 1. Demographic Information of the Participants

\begin{tabular}{ccc}
\hline Gender & & \\
\hline Male & 37 & 67.3 \\
Female & 18 & 32.7 \\
\hline Age & & \\
\hline $30-39$ & 2 & 3.6 \\
$40-49$ & 13 & 23.6 \\
Above 50 & 40 & 72.7 \\
\hline Years of Experience & & 30.9 \\
\hline $1-5$ & 17 & 41.8 \\
$6-10$ & 23 & 27.3 \\
\hline and above & 15 &
\end{tabular}

As shown in table (1), the participants consisted of 37 male and 18 female faculty members. The participants with age ranges from 30-39 were 2, participants with age from 40 to 49 were 13 , and the participants with age from 50 and above were 40 faculty members.

\section{Research Instrument}

As mentioned earlier, a questionnaire adapter from Okoduwa et al., (2018) was used to collect the data of the present study. The questionnaire consisted of 24-items distributed to three sections, items (1-5) asking about the perceptions toward research publication, items (616) were about the challenges facing faculty members in research production, and items from (17-24) were about the suggestions to improve research production. The participants were asked to answer the questionnaire items based on a six-point Liker-scale, ranging from 1 'strongly disagree' to 6 'strongly agree. The questionnaire was sent online to the faculty members teaching at the Faculty of Languages and Translation at King Khalid University. The researcher used the Statistical Package for Social Sciences (SPSS) software (Version 22.0). Different statistical functions have been used to get the results of the present study. These functions included means, standard deviations, frequencies, and percentages.

\section{Results and Discussion}

The present study aims at exploring the perceptions, challenges, and suggestions for improving research production at King Khalid University. This section seeks to present the findings of this study. The findings will be presented and tabulated according to the research questions. Perceptions toward Research Publication this section seeks to provide answers to the first research question: How do faculty members at King Khalid University perceive research publication? Means and standard deviations were used to get answers for this question (see Table 2). As shown in table (2), the participants perceived research publication as a significant factor in career progression, this item got the highest mean score (M=5.59, $\mathrm{SD}=.762)$, followed by the importance of research in improving academia $(\mathrm{M}=5.47, \mathrm{SD}=$ .835). The majority of participants show research as means to disseminate information $(\mathrm{M}=$ $5.34, \mathrm{SD}=.725)$; while others consider research publication as their interest $(\mathrm{M}=5.00, \mathrm{SD}=$ 1.12). A considerable number of the participants illustrate that they publish research because of their peer pressure $(\mathrm{M}=3.16, \mathrm{SD}=1.52)$. 
Table 2. Perceptions toward Research Publication

\begin{tabular}{cccc}
\hline Item & N & Mean & Std. Deviation \\
\hline Research publication is important for career & 55 & 5.58 & .762 \\
$\begin{array}{c}\text { progression } \\
\text { Research is important to improve academia }\end{array}$ & 55 & 5.47 & .835 \\
Research is important to disseminate & 55 & 5.34 & .725 \\
$\begin{array}{c}\text { information } \\
\text { The research publication is my interest }\end{array}$ & 55 & 5.00 & 1.12 \\
I try to publish research because of peer & 55 & 3.16 & 1.52 \\
$\begin{array}{c}\text { pressure } \\
\text { Valid N (listwise) }\end{array}$ & 55 & & \\
\hline
\end{tabular}

\section{Challenges of Research Production}

This part tends to give answers to the second research question: What are the challenges facing the faculty members at King Khalid University in research publication? Mean scores and standard deviations were used to obtain the results of this question (see Table 3).

Table 3. Challenges Facing Faculty Members in Research Publication

\begin{tabular}{cccc}
\hline Item & $\mathbf{N}$ & Mean & Std. Deviation \\
\hline The waiting time for manuscript publication is too long & 55 & 4.69 & 1.38 \\
Insufficient time for publication & 55 & 4.40 & 1.27 \\
Inadequate research training workshops & 55 & 4.40 & 1.52 \\
Lack of professional mentorship & 55 & 4.32 & 1.37 \\
Inadequate research facilities & 55 & 4.25 & 1.55 \\
Lack of research funding & 55 & 4.20 & 1.41 \\
High publication fees & 55 & 3.80 & 1.49 \\
Inadequate research experience & 55 & 3.78 & 1.51 \\
There is no departmental motivation & 55 & 3.72 & 1.55 \\
Fear of manuscript rejection & 55 & 2.92 & 1.45 \\
I have no research writing experience & 55 & 2.49 & 1.71 \\
\hline Valid N (listwise) & $\mathbf{5 5}$ & & \\
\hline
\end{tabular}

As illustrated in table (3), the participants have mentioned different challenges facing them when they want to publish research papers. The most prominent challenges were because of the waiting time it takes to publish research $(\mathrm{M}=4.69, \mathrm{SD}=1.38)$; the insufficient time they have for publication $(\mathrm{M}=4.40, \mathrm{SD}=1.27)$; and inadequate research training workshops $(\mathrm{M}=4.40, \mathrm{SD}=1.52)$. Among other challenges reported by the participants, lack of professional mentorship $(\mathrm{M}=4.32, \mathrm{SD}=1.37)$; inadequate research facilities $(\mathrm{M}=4.25$, $\mathrm{SD}=1.55)$; and lack of research funding $(\mathrm{M}=4.20, \mathrm{SD}=1.41)$ have occupied an important place with this regard. The participants have also reported high publication fees $(\mathrm{M}=3.80$, $\mathrm{SD}=1.49)$; inadequate research experience. $(\mathrm{M}=3.78, \mathrm{SD}=1.51)$; lack of departmental motivation $(\mathrm{M}=3.72, \mathrm{SD}=1.55)$; fear of manuscript rejection $(\mathrm{M}=2.92, \mathrm{SD}=1.45)$; and lack of experience in research writing $(\mathrm{M}=2.49, \mathrm{SD}=1.71)$ as major challenges they face in research publication.

\section{Suggestions for Improving Research Production}

This section seeks to present the findings of the third research question: What are the recommendations to improve research publication as suggested by faculty members at King 
Khalid University? Mean scores and standard deviations were also used in this part to get the results of this question (see Table 4). Table (4) above shows some suggestions reported by the participants to improve research production at King Khalid University. The participants mentioned that there should be research training programs $(\mathrm{M}=5.29, \mathrm{SD}=.83)$; there should be incentives for research $(\mathrm{M}=5.14, \mathrm{SD}=.98)$; there should be appropriate research facilities $(\mathrm{M}=5.07, \mathrm{SD}=1.03)$; assistance to pay publication fees $(\mathrm{M}=4.96, \mathrm{SD}=1.20)$; conduct collaborative research $(\mathrm{M}=4.89, \mathrm{SD}=1.16)$; provide research mentorship $(\mathrm{M}=4.74, \mathrm{SD}=$ $1.25)$; the existence of annual publication target $(\mathrm{M}=4.18, \mathrm{SD}=1.57)$; and the mandatory of research publication in the institution $(\mathrm{M}=3.85, \mathrm{SD}=1.49)$.

Table 4. Suggestions for Improving Research Production among Faculty Members

\begin{tabular}{cccc}
\hline Item & N & Mean & Std. Deviation \\
\hline There should be research training programs & 55 & 5.29 & .83 \\
There should be incentives for research & 55 & 5.14 & .98 \\
There should be appropriate research facilities & 55 & 5.07 & 1.03 \\
There should be assistance to pay publication fees & 55 & 4.96 & 1.20 \\
Collaborative research is important to improve & 55 & 4.89 & 1.16 \\
$\quad$ research production & 55 & 4.74 & 1.25 \\
$\quad$ There should be research mentorship & 55 & 4.18 & 1.57 \\
$\begin{array}{c}\text { There should be an annual publication target } \\
\text { Research publication should be mandatory in our } \\
\text { institution }\end{array}$ & 55 & 3.85 & 1.49 \\
\hline Valid N (listwise) & $\mathbf{5 5}$ & & \\
\hline
\end{tabular}

\section{Discussion}

The findings showed different perceptions toward research publication at King Khalid University. Some of these perceptions include the importance of research in career progress and in improving academia. These perceptions have been mentioned by other researchers such as Okoduwa et al. (2018). The research publication is inevitably important to improve careers such as academic promotion and to get research awards. These results concur with Shauman \& Xie (2003) and Gonzalez-Bambila \& Veloso (2007) who found research as an important indicator of faculty member's success in his/her institution. To the best of the researcher's knowledge, this study is one of the very few studies that investigated the perceptions toward research production in the context of Saudi Arabia.

The participants also reported some challenges they face in research production such as the waiting period to get a response from journals, and the insufficient time allocated for publication, and the lack of research mentorship and facilities. These results are consistent with some previous studies (Fawzi \& Al-Hattami, 2015), and Dadipoor et al. (2018) who have mentioned these challenges in their studies. In the present study, a considerable number of the participants reported a lack of research funding as one of the main factors to publish research at King Khalid. The researcher himself disagrees with this result as he belongs to the same institution. King Khalid University has different fund programs allocated for research publication. These programs include General Research Program, Small Research Program, and Big Research Program. Each one of those programs has specific research papers to be published in order for the faculty members to get the fund. Karloak (2012) emphasized the fact that some faculty members are aware of the significance of the research, but they do not transfer that significance and awareness into practice. Concerning the suggestions provided by the participants to improve research production, the most important suggestion was to provide research training programs. This might indicate that the faculty members do not possess sufficient experience in research publication. In Okoduwa et al. (2018) study, the 
participants pointed out that research publication should be compulsory to increase the rate of published research papers rate in Nigeria. The participants of the present study did not encourage the idea of mandatory research publication; the mean score of this suggestion occupies the last place. In fact, the research production at King Khalid University is mandatory and it is a prerequisite for contract renewal and promotion. However, the rate of research publication at the university is relatively low. Therefore, there should be practical steps to be taken by the university to increase research production at the university; especially in light of the university's endeavors to be among the best 200 universities in the world by (2030).

\section{Conclusion}

The main purpose of the present study was to explore the perceptions and challenges concerning research production. It also aimed at providing some suggestions for improving research production at King Khalid University. The results of this study have revealed that faculty members acknowledge the importance of research publication in their career progress. They also provided some challenges facing them when they intend to write research such as the insufficient time allocated for research, lack of research training, and lack of research facilities. Based on these results, the faculty members should be given more opportunities to do research. The policymakers at the university should take serious steps to address the challenges of research production and take research initiatives to increase faculty members' research potential. The findings of this study could be the cornerstone for further studies on research production. It is highly recommended to have similar comparative studies in this regard with a larger number of participants from different institutions.

\section{Acknowledgment}

The authors extend their appreciation to the Deanship of Scientific Research at King Khalid University for funding this work through Big Research Groups under grant number (RGP.2 /103/42).

\section{References}

Abouchedid, K., \& Abdelnour, G. (2015). Faculty research productivity in six Arab countries. International Review of Education, 61(5), 673-690. https://doi.org/10.1007/s11159-015-9518-5.

Alzahrani, J. (2011). Overcoming Barriers to improve research productivity in Saudi Arabia. International Journal of Business and Social Science, 2(19), 50-57. http://ijbssnet.com/journals/Vol_2_No_19_Special_Issue_October_2011/5.pdf.

Angaiz, D. (2015). An investigation of teachers' education faculty research productivity in public sector universities of Pakistan. Unpublished doctoral dissertation, Dowling College, New York, USA.

Batooli, Z., \& Nazari, M. (2014). The features of social research network for facilitating research activities from medical sciences researchers' perspective. Journal of Payavard Salamat, 8(4), 316-331.

Burton, H., \& Walters, L. (2013). Access to Medicare-funded annual comprehensive health assessments for rural people with intellectual disability. Rural and remote health 13(3):2278. https://doi.org/10.22605/RRH2278.

Dadipoor, S., Ramezankhani, A., Aghamolaei, T., Rakhshani, F., \& Safari-Moradabadi, A. (2018). Evaluation of health literacy in the Iranian population. Health Scope, 7(3), e62212. http://eprints.hums.ac.ir/5903/. 
Fawzi, H., \& Al-Hattami, A. (2017). Faculty production of research papers: Challenges and recommendations. International Journal of Humanities and Social Science, 7(2), 221228.

Gonzalez-Brambila, C. and F. Veloso (2007). The determinants of research productivity: A study of Mexican researchers. Research Policy, 36(7) 1035-1051. https://doi.org/10.1016/j.respol.2007.03.005.

Hagan, J. L., Armbruster, P., \& Ballard, R. (2019). Barriers to research among faculty at a health sciences university. American Journal of Educational Research, 7(1), 44-48. http://article.scieducationalresearch.com/pdf/EDUCATION-7-1-7.pdf.

Hoffmann, K., Berg, S., \& Koufogiannakis, D. (2014). Success in research: Factors that contribute to increased research productivity across librarianship and other disciplines. Paper presented at the 42ndAnnual Conference of CAIS, Canadian Association for Information Science, Brock University - St. Cathartines, Ontario, May 28- 30, 2014. https://doi.org/10.29173/cais852.

Karloak, M. (2012). Bahrain's tertiary education reform: a step towards sustainable economic development. Revue des mondesmusulmans et de la Méditerranée [English], 131(3). https://doi.org/10.4000/remmm.7665.

Kasetsart, J. (2009). Factors Affecting Research Productivity of Faculty Members in Government Universities: Lisrel and Neural Network Analyses. Social Sciences, 30, 67 -78. https://so04.tci-thaijo.org/index.php/kjss/article/view/246489.

Kendagor, S. T, Kosgei D, Tuitoek D., and Chelangat S. (2012). Factors affecting research productivity in public universities of Kenya: The case of Moi University, Eldoret. Journal of Emerging Trends in Economics and Management Sciences, 3(5),475-484. https://hdl.handle.net/10520/EJC127672.

Okoduwa, S. I., Abe, J. O., Samuel, B. I., Chris, A. O., Oladimeji, R. A., Idowu, O. O., \& Okoduwa, U. J. (2018). Attitudes, Perceptions, and Barriers to Research and Publishing Among Research and Teaching Staff in a Nigerian Research Institute. Frontiers in Research Metrics and Analytics, 3, 26. https://doi.org/10.3389/frma.2018.00026.

Shauman, K. A., \& Xie, Y. (2003). Explaining sex differences in publication productivity among postsecondary faculty. In Equal rites, unequal outcomes (pp. 175-208). Springer, Dordrecht. https://doi.org/10.1007/978-94-010-0007-9_8.

Sotodeh Asl, N., Ghorbani, R., \& Rashidy-Pour, A. (2014). Viewpoints of faculty members of Semnan University of Medical Sciences about research barriers. Koomesh, 1-7. http://eprints.semums.ac.ir/346/.

Webber, K. L. (2010). Measuring faculty productivity. In: Shin, et al [Eds], University Rankings: Theoretical Basis, Methodology and Impacts on Global Higher Education, 105-121, New York: Springer.

Zhou, J. (2014) Problems teachers face when doing action research and finding possible

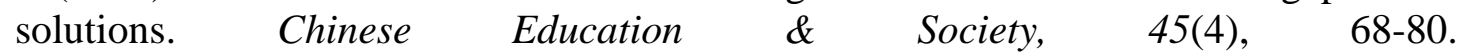
https://doi.org/10.2753/CED1061-1932450405. 